Riwayat draf artikel: Diserahkan 23-02-2021 Diterima 06-03-2021

\section{Peningkatan Aktifitas dan Hasil Belajar Bahasa Indonesia melalui Metode Speed Reading pada Siswa Kelas VIII SMP Negeri 2 Alla Kabupaten Enrekang}

Sitti

SMP Negeri Alla Kabupaten Enrekang

Email: Sittispd9@gmail.com

\begin{abstract}
ABSTRAK: Penelitian ini bertujuan untuk meningkatkan aktifitas dan hasil belajar bahasa Indonesia melalui metode speed reading pada siswa kelas VIII SMP Negeri 2 Alla Kabupaten Enrekang. Peneliti menerapkan prosedur Penelitian Tindakan Kelas (PTK), dengan subjek penelitian siswa kelas VIII-A SMP Negeri 2 Alla Kabupaten Enrekang, yaitu: 15 siswa laki-laki dan 15 siswa perempuan. PTK ini dirancang ke dalam 2 siklus, dimana masing-masing siklus terdiri dari 3 kali pertemuan. Instrumen penelitian yang digunakan adalah instrumen tes dan non-tes. Adapun indikator keberhasilan adalah apabila siswa yang memperoleh skor minimal 65 mencapai 85\%. Hasil penelitian menunjukkan bahwa metode speed reading dapat meningkatkan aktifitas dan hasil belajar bahasa Indonesia siswa. Oleh karena itu, penggunaan metode speed reading dapat dijadikan pendekatan pembelajaran bagi guru di kelas.
\end{abstract}

Kata Kunci: Aktifitas, Hasil Belajar, Metode Speed Reading.

ABSTRACT: This study aims to improve Indonesian language activities and learning outcomes through the Speed Reading method in class VIII students of SMP Negeri 2 Alla District Enrekang. The researcher applied the Classroom Action Research Procedure (PTK), with the research subjects of class VIII-A students of SMP Negeri 2 Alla Regency Enrekang, namely: 15 male students and 15 female students. This PTK was designed into 2 cycles, where each cycle consisted of 3 meetings. The research instrument used is a test and non-test instrument. The success indicator is if students who obtain a minimum score of 65 reach $85 \%$. The results showed that the speed reading method could increase the activities and learning outcomes of Indonesian students. Therefore, the use of the Speed Reading method can be used as a learning approach to teachers in class

Keywords: Activities, Learning Outcomes, Speed Reading Method.

\title{
PENDAHULUAN
}

Keterampilan berbahasa yang dipelajari di sekolah berdasarkan kurikulum meliputi empat aspek, yaitu menyimak, berbicara, membaca, dan menulis. Hal ini menunjukkan bahwa keempat aspek tersebut sangat berperan penting dalam pengajaran suatu bahasa di sekolah. Salah satu dari empat aspek tersebut adalah membaca. Membaca sangat membantu proses belajar menjadi lebih efektif, karena siswa yang gemar membaca akan memperoleh informasi dan pengetahuan baru dari bacaan yang dibacanya. Membaca juga dapat memberikan kesenangan atau hiburan bagi seseorang. 
Membaca sebagai salah satu keterampilan berbahasa menduduki posisi dan peran yang sangat penting dalam konteks kehidupan manusia. Masyarakat yang gemar membaca akan memperoleh pengetahuan dan wawasan baru, serta dapat meningkatkan kecerdasannya, sehingga mereka lebih mampu menjawab tantangan hidup pada masa-masa mendatang (Rahim 2005: 1). Dari uraian tersebut, dapat disimpulkan bahwa masyarakat yang gemar membaca akan mendapatkan informasi dan pengetahuan baru untuk bekal dalam menghadapi tantangan kehidupan. Banyaknya informasi yang beredar di masyarakat menimbulkan tekanan bagi para pendidik agar lebih selektif dalam menyiapkan bacaan yang sesuai untuk siswanya-siswanya. Bekal kemampuan membaca, siswa akan memperoleh pengetahuan, serta mempermudah pola pikirnya untuk berpikir lebih kritis. Melalui pembelajaran membaca, siswa diharapkan dapat memberikan tanggapan yang tepat pada informasi yang telah dibaca. Untuk mencapai semua itu, pembelajaran membaca harus diterapkan dengan baik agar keterampilan membaca yang dimiliki siswa dapat meningkat.

Nurhadi (2004: 11) menyatakan bahwa hal-hal yang harus diperhatikan untuk meningkatkan keterampilan membaca adalah (a) menyadari adanya berbagai variasi tujuan membaca yang berbeda antara satu kegiatan membaca dengan kegiatan membaca yang lain; (b) selalu merumuskan secara jelas setiap kegiatan membaca; (c) memerlukan berbagai pengembangan strategi membaca yang selaras dengan ragam tujuan membaca; (d) memerlukan latihan membaca dengan berbagai variasi tujuan membaca; (e) menyadari bahwa seseorang yang mempunyai daya baca tinggi akan mampu memanfaatkan teknik membaca yang bervariasi sesuai dengan tujuan membaca yang diinginkan. Oleh karena itu, dapat disimpulkan bahwa dalam meningkatkan keterampilan membaca seseorang, tujuan membaca yang bervasiasi harus diperhatikan. Tujuan kegiatan membaca yang satu dengan kegiatan membaca yang lainnya berbeda, sehingga dalam pelaksanaan keterampilan membaca tersebut tetap harus mengacu pada tujuan dari kegiatan membaca yang akan dilakukan. Rutinitas seseorang yang padat akan membuat orang tersebut memiliki waktu baca yang sedikit. Maka kemampuan membaca cepat sangat diperlukan untuk mengantisipasi masalah tersebut. Membaca cepat akan mempermudah dalam menangkap informasi yang terdapat dalam sebuah bacaan serta memahami isi bacaan. Selain itu, kemampuan membaca cepat akan mempermudah untuk menemukan suatu informasi yang dibutuhkan dalam waktu yang cepat meskipun informasi tersebut terdapat dalam bacaan yang panjang.

Hasil studi para ahli membaca di Amerika mengungkapkan, kecepatan yang memadai untuk siswa tingkat akhir sekolah dasar kurang lebih 200 kpm, siswa lanjutan tingkat pertama antara $200-250 \mathrm{kpm}$, siswa tingkat lanjutan atas antara $250-325 \mathrm{kpm}$, dan tingkat mahasiswa $325-400 \mathrm{kpm}$ dengan pemahaman isi bacaan minimal $70 \%$. Adapun di Indonesia KEM minimal untuk klasifikasi membaca adalah SD (140 kpm), SLTP (140-175 kpm), SMU (175-245 kpm), dan PT (245-280) (Subyantoro, dkk 2002: 33). Dari uraian tersebut dapat disimpulkan bahwa standar kecepatan yang harus dimiliki seorang siswa berbeda berdasarkan jenjang usianya. Kemampuan membaca cepat pada kenyataannya 
tidak banyak dimiliki oleh siswa. Kebanyakan siswa memiliki kemampuan membaca cepat dibawah standar yang seharusnya. Berdasarkan keadaan tersebut, perlu diupayakan cara untuk meningkatkan keterampilan membaca, khususnya ketampilan membaca cepat.

Berdasarkan uraian di atas jelas bahwa pengajaran membaca di sekolah berperan penting dalam peningkatan prestasi belajar siswa, sehingga memerlukan pembinaan dan pengembangan, serta perhatian khusus bagi para guru untuk melakukan peningkatan kemampuan membaca cepat terhadap prestasi siswa seperti pada kelas VIII SMP Negeri 2 Alla Kabupaten Enrekang. Oleh sebab itu, kepada siswa perlu ditanamkan minat baca sejak masih duduk di bangku sekolah. Guru hanya mengajarkan siswa untuk membaca tanpa disertai dengan metode yang dapat memudahkan siswa untuk membaca dengan cepat serta dapat menemukan pokok pikiran bacaan dengan cepat pula, dan guru belum pernah menetapkan metode speed reading dalam pembelajaran. Kedua, berdasarkan keterangan guru dan hasil observasi, kemampuan membaca siswa masih dalam tahap kata per kata. Ketiga, berdasarkan keterangan guru, siswa jika diberi pelajaran membaca tampak kurang berminat dan kurang tertarik dengan bacaan yang disajikan. Keempat, berdasarkan hasil wawancara dengan siswa, siswa ingin pembelajaran yang menyenangkan karena selama ini siswa menganggap pembelajaran membaca cepat sangat membosankan.

Berdasarkan uraian di atas, sangat jelas bahwa pengajaran membaca di sekolah memegang peranan yang penting dalam meningkatkan prestasi belajar siswa, sehingga memerlukan pembinaan dan pengembangan, serta perhatian khusus bagi para guru untuk meningkatkan kemampuan membaca cepat. Dalam hal ini penulis tertarik untuk mengetahui: Apakah penerapan metode speed reading dapat meningkatkan aktivitas belajar bahasa Indonesia siswa kelas VIII SMP Negeri 2 Alla Kabupaten Enrekang? dan apakah penerapan metode speed reading dapat meningkatkan hasil belajar bahasa Indonesia siswa kelas VIII SMP Negeri 2 Alla Kabupaten Enrekang ?

\section{METODE PENELITIAN}

Penelitian ini digolongkan ke dalam penelitian tindakan kelas. Subjek Penelitian ini adalah siswa kelas VIII-A SMP Negeri 2 Alla Kabupaten Enrekang yang berjumlah 30 orang, terdiri atas 15 siswa laki-laki dan 15 siswa perempuan. Proses kerja penelitian tindakan kelas ini dirancang ke dalam dua siklus. Tiap siklus diadakan selama 3 kali pertemuan. Instrumen Penelitian yang digunakan adalah untuk pengumpulan data dalam penelitian tindakan kelas ini berupa instrumen tes dan non-tes.

Data yang telah diperoleh dari hasil penelitian dianalisis secara kuantitatif dan kualitatif. Analisis kualitatif digunakan untuk menjelaskan hasil-hasil tindakan yang mengarah pada peningkatan keaktifan siswa selama mengikuti 
proses belajar mengajar. Analisis kuantitatif dianalisis dengan menggunakan statistik deskriptif tentang nilai rata-rata, nilai maksimum, nilai minimum, dan rentang skor. Kategorisasi standar tersebut adalah sebagai berikut: Nilai 8,5 10,0 kategori sangat baik. Nilai 6,5-8,4 kategori baik. Nilai 5,5-6,4 kategori sedang. Nilai 3,5-5,4 kategori kurang Nilai $0-3,4$ kategori sangat kurang.

\begin{tabular}{|c|c|}
\hline \multicolumn{1}{|c|}{ Tabel 1 } & Ketuntasan Hasil Belajar \\
\hline Skor & Kategori \\
\hline $85 \%-100 \%$ & Sangat baik \\
\hline $70 \%-84 \%$ & Baik \\
\hline $55 \%-69 \%$ & Cukup \\
\hline $46 \%-54 \%$ & Kurang \\
\hline $0 \%-45 \%$ & Sangat kurang \\
\hline
\end{tabular}

\section{Indikator Keberhasilan}

Menurut ketentuan KKM yang ada di SMP Negeri 2 Alla Kabupaten Enrekang, siswa dikatakan tuntas belajar apabila memperoleh skor minimal 65 dari skor ideal dengan ketuntasan individual 65 ke atas dan klasikal apabila 85\% dari jumlah siswa yang tuntas belajar.

\section{HASIL PENELITIAN}

\section{Observasi Aktivitas Siswa pada Siklus I}

Pada siklus I terjadi peningkatan kualitas belajar dilihat dari segi hasil terhadap mata pelajaran bahasa Indonesia dalam membaca cepat, terjadi pula perubahan aktivitas siswa dalam proses pembelajaran. Perubahan tersebut merupakan data yang diperoleh dari lembar observasi pada setiap pertemuan yang dicatat pada tiap siklus. 30 siswa yang menjadi subjek penelitian kelas VIII SMP Negeri 2 Alla Kabupaten Enrekang, Kehadiran siswa mengikuti pelajaran rata-rata mencapai $85,55 \%$. Siswa yang yang antusias dan semangat mengikuti pelajaran rata-rata mencapai $53,33 \%$. Siswa yang memperhatikan penjelasan guru rata-rata mencapai $53,33 \%$. Siswa yang mengajukan pertanyaan rata-rata mencapai $48,88 \%$. Siswa yang aktif menjawab dan berkomentar mengenai materi yang dijelaskan rata-rata mencapai $47,77 \%$. Siswa yang bersemangat membaca cepat teks bacaan dengan menggunakan metode gerak mata rata-rata mencapai 56,66\%. Siswa yang mampu merefleksikan proses dari hasil pembelajaran membaca cepat teks bacaan rata-rata mencapai $48,88 \%$. Siswa yang mampu mengumpulkan hasil tugas dengan tertib rata-rata mencapai $45,55 \%$

\section{Hasil Tes Akhir Siklus I}

Berdasarkan hasil analisis deskriptif sebagaimana tercantum pada lampiran, maka rangkuman statistik skor hasil belajar siswa kelas siswa kelas VIII SMP Negeri 2 Alla Kabupaten Enrekang adalah sebagai berikut: 
Tabel 2 Statistik hasil belajar siswa kelas VIII SMP Negeri 2 Alla Kabupaten Enrekang

\begin{tabular}{|l|c|}
\hline \multicolumn{1}{|c|}{ Statistik } & Nilai Statistik \\
\hline Subjek & 30 \\
Skor Ideal & 100 \\
Skor Tertinggi & 75 \\
Skor Terendah & 50 \\
Rentang Skor & 20 \\
Skor Rata-Rata & 63.83 \\
\hline
\end{tabular}

Pada tabel di atas dapat disimpulkan bahwa hasil belajar bahasa Indonesia kelas VIII SMP Negeri 2 Alla Kabupaten Enrekang setelah dilakukan dengan penerapan keterampilan membaca cepat diperoleh skor yang menunjukkan bahwa pada siklus I dengan jumlah siswa 30 orang mempunyai perolehan nilai skor tertinggi 75 dan nilai skor terendah 50 dengan rentang skor dari selisih perolehan skor tertinggi dan skor terendah yaitu 20. Dari hasil analisis data statistik hasil belajar pada siklus I diperoleh skor rata-rata dengan nilai 63,83 .

\section{Observasi Aktivitas Siswa Pada Siklus II}

Berdasarkan tabel di atas diperoleh bahwa dari 30 siswa yang menjadi subjek penelitian kelas VIII SMP Negeri 2 Alla Kabupaten Enrekang, Kehadiran siswa mengikuti pelajaran rata-rata mencapai $95,55 \%$. Siswa yang yang antusias dan semangat mengikuti pelajaran rata-rata mencapai $81,11 \%$. Siswa yang memperhatikan penjelasan guru rata-rata mencapai $88,88 \%$. Siswa yang mengajukan pertanyaan rata-rata mencapai $88,88 \%$. Siswa yang aktif menjawab dan berkomentar mengenai materi yang di jelaskan rata-rata mencapai $87,77 \%$. Siswa yang bersemangat membaca cepat teks bacaan dengan menggunakan metode gerak mata rata-rata mencapai 92,22\%. Siswa yang mampu merefleksikan proses dari hasil pembelajaran membaca cepat teks bacaan ratarata mencapai $88,88 \%$. Siswa yang mampu mengumpulkan hasil tugas dengan tertib rata-rata mencapai $90,00 \%$.

\section{PEMBAHASAN}

\section{Hasil Tes Akhir Siklus II}

Berdasarkan hasil analisis deskriptif sebagaimana tercantum pada lampiran, maka rangkuman statistik skor hasil belajar bahasa Indonesia kelas VIII SMP Negeri 2 Alla Kabupaten Enrekang dapat disimpulkan bahwa hasil belajar bahasa Indonesia kelas VIII SMP Negeri 2 Alla Kabupaten Enrekang pada siklus II setelah dilakukan dengan penerapan keterampilan membaca cepat pada diperoleh skor yang menunjukkan bahwa pada siklus II dengan jumlah siswa 30 orang, mempunyai perolehan nilai skor tertinggi 85 dan nilai skor terendah 55 dengan rentang skor dari selisih perolehan skor tertinggi dan skor terendah yaitu 
30. Dari hasil analisis data statistik hasil belajar pada siklus II diperoleh skor ratarata dengan nilai 75,16 . Setelah diamati dan didiskusikan serta dilakukan refleksi selama pelaksanaan penelitian tindakan di lapangan, maka dapatlah dipaparkan seperti pada tabel berikut:

Tabel 3 Perbandingan Skor Tiap Siklus

\begin{tabular}{|l|l|l|l|l|l|l|l|}
\hline \multirow{3}{*}{ Siklus } & \multicolumn{3}{|c|}{ Skor Perolehan Siswa } & \multicolumn{2}{c|}{ Tuntas } & \multicolumn{2}{c|}{ Tidak tuntas } \\
\cline { 2 - 8 } & Minimum & Maksimum & $\begin{array}{r}\text { Rata- } \\
\text { rata }\end{array}$ & Frekuensi & Persentase & Frekuensi & Persentase \\
\hline Siklus I & 50 & 75 & 63.83 & 24 & 80 & 6 & 20 \\
Siklus II & 55 & 85 & 75.16 & 27 & 90 & 3 & 10 \\
\hline
\end{tabular}

Tingkat kehadiran siswa pada saat pembelajaran berlangsung dari siklus I yaitu $85,55 \%$ meningkat ke siklus II yaitu $95,55 \%$. Hal ini menandakan bahwa metode atau cara mengajar juga berpengaruh langsung terhadap kehadiran belajar siswa di sekolah. Siswa yang antusias dan semangat mengikuti pembelajaran dari siklus I yaitu 53,33\% meningkat ke siklus II yaitu $81,11 \%$. Peningkatan disebabkan perhatian siswa terhadap pelajaran lebih besar karena penerapan keterampilan membaca cepat dalam pembelajaran bahasa Indonesia. Siswa yang memperhatikan materi yang diajarkan pada siklus I, yaitu 53,33\% meningkat menjadi $88,88 \%$. Hal ini disebabkan oleh siswa cenderung tertarik pada penerapan keterampilan membaca cepat karena pada pembelajaran ini keterkaitan langsung dengan keseharian siswa baik dilingkungan rumah maupun di sekolah.

Membaca mempunyai peranan sosial yang sangat penting dalam kehidupan manusia sepanjang masa sebab membaca merupakan alat komunikasi yang sangat diperlukan dalam masyarakat. Dunia kita adalah dunia baca. Untuk mengetahui perkembangan dan sebagian ilmu pengetahuan dan informasi lainnya, maka diperlukan membaca karena dengan membaca kita dapat mengenal dunia baru di sekitar kita, bangsa lain, masa lalu dan lain sebagainya.Siswa yang bertanya tentang materi yang belum dimengerti meningkat pada siklus I, yaitu $48,88 \%$ menjadi $88,88 \%$ pada siklus II. Ini menunjukkan bahwa rasa ingin tahu siswa terhadap materi cukup besar karena siswa merasa pembahasan mengenai keterampilan membaca cepat sangat menarik, menyenangkan, dan memperbesar perhatian siswa, serta dalam membaca tidak menutup kemungkinan akan memperkecil ketinggalan informasi yang semakin berkembang. Siswa yang aktif dalam menjawab dan berkomentar mengenai materi pada saat pembelajaran. keaktifan siswa meningkat dari siklus I, yaitu $47,77 \%$ menjadi $87,77 \%$ pada siklus II. Hal ini tentu disebabkan siswa tertarik dan merasa senang karena penerapan keterampilan membaca cepat pada pembelajaran bahasa Indonesia. Siswa yang bersemangat membaca cepat mengalami peningkatan dari siklus I, yaitu $56,66 \%$ menjadi $92,22 \%$ pada siklus II. Peningkatan ini menunjukkan bahwa siswa memahami dengan baik pentingnya membaca dimana buku adalah merupakan sarana, sumber, dan jendela dunia karena jika ingin mengetahui berbagai informasi di berbagai belahan dunia, sehingga harus banyak membaca buku. Oleh karena itu, sejak dini upaya 
menumbuhkan minat baca harus ditumbuhkan khususnya melalui jenjang pendidikan sekolah. Siswa yang mampu merefleksikan proses dari pembelajaran membaca cepat teks bacaan mengalami peningkatan dari siklus I yaitu $48,88 \%$ menjadi $88,88 \%$ pada siklus II. Siswa yang mampu mengumpulkan hasil tugas dengan tertib mengalami peningkatan dari siklus I yaitu 45,55\% menjadi $90,00 \%$.

\section{SIMPULAN}

Dari hasil penelitian tindakan kelas yang dilakukan selama dua siklus, maka dapat disimpulkan sebagai berikut: 1) Penerapan metode speed reading dapat meningkatkan hasil belajar bahasa Indonesia siswa kelas VIII SMP Negeri 2 Alla Kabupaten Enrekang dari rata-rata skor hasil akhir siklus I adalah 63.83 menjadi 75,16 pada siklus II. Begitu juga dengan ketuntasan belajar dari siklus I adalah $80 \%$ meningkat hingga $90 \%$ pada siklus II; 2) Terjadi peningkatan kualitas pembelajaran ditandai dengan meningkatnya aktifitas siswa dalam proses pembelajaran sesuai dengan hasil observasi selama tindakan kelas berlangsung dari siklus I adalah $61,85 \%$ meningkat menjadi $72,77 \%$ pada siklus II. Hal ini dilihat dari hasil observasi siswa yang dilakukan oleh peneliti mulai dari siswa yang hadir pada saat pembelajaran, siswa yang memperhatikan materi yang diajarkan, siswa yang melakukan kegiatan lain pada saat pembelajaran, siswa yang keluar masuk pada proses pembelajaran, siswa yang bertanya tentang apa yang belum dimengerti, siswa yang mengajukan diri untuk membacakan teks bacaan dengan suara nyaring di depan kelas, siswa yang aktif pada saat menyelesaikan teks bacaan tepat waktu, siswa yang berpartisipasi dan bekerjasama dalam kelompok, hingga siswa yang aktif untuk memberikan tanggapan pada kelompok mempresentasikan laporannya.

\section{UCAPAN TERIMA KASIH}

Penulis mengucapan terima kasih kepada Kepala Sekolah, guru-guru dan siswa kelas VIII SMP Negeri 2 Alla Kabupaten Enrekang, keluarga, teman-teman, dan semua pihak yang telah banyak memberikan bantuan dalam penyelesaian penelitian PTK hingga tahap publikasi artikel ini. Penulis berharap semoga semua upaya ini mendapat berkah dari Allah. Ucapan terimakasih juga diberikan kepada seluruh editor tim Journal of Education and Teaching (JET) FKIP Universitas Muhammadiyah Kendari.

\section{DAFTAR PUSTAKA}

Hamalik, Oemar. (2003). Proses Belajar Mengajar. Cet. II. Jakarta: Bumi Akasara Hamalik, Oemar. (2011). Kurikulum dan Pembelajaran. Jakarta: Bumi Aksara Hidayah, A. (2012). Membaca Super Cepat. Jakarta: Laskar Aksara

Hidayat, R. (1997). Pengetesan Kemampuan Membaca Komunikatif. Jakarta: Inter Nusa.

Junus, H. A. M dan A. Fatimah J. (2010). Analisis Kesalahan Berbahasa.Makassar: Badan Penerbit UNM. 
Muhammad Noer. Speed Reading for Beginner. http://www.muhammadnoer.com. Di akses tanggal 8 Januari 2017

Nurindah. (2001). Hubungan antara Minat Baca dengan Prestasi Belajar Siswa Kelas VIII SMP Negeri 1 Bontolempangan Kecamatan Bontolempangan Kabupaten Gowa. Unismuh Makassar.

Nurhadi. (2004). Bagaimana Meningkatkan Kemampuan Membaca. Bandung: Sinar Baru Algesindo.

Rani Andayani. (2010). Peningkatan Keterampilan Membaca dengan Menggunakan Metode Speed Reading pada Siswa Kelas VIII SMP Negeri 1 Bontolempangan Kecamatan Bontolempangan Kabupaten Gowa. Unismuh Makassar.

Sanjaya, Wina. (2010). Strategi Pembelajaran Berorientasi Standar Proses Pendidikan. Cet. VII: Jakarta: Premada Media Group.

Sardiman. (2011). Interaksi dan Motivasi Belajar Mengajar. Jakarta: Raja Grafindo Persada.

Subyantoro. (2002). Studi Efektivitas Pelaksanaan Pelatihan Baca dan Tulis Tingkat Nasional Tahun 2002. Halaman 29-50. Semarang: Fakultas Bahasa dan Seni UNNES. 